\title{
SEMBLANZA DEL POETA COSTARRICENSE LISÍMACO CHAVARRÍA: PRESENCIA EN LAS LETRAS NACIONALES Y EN LA MEMORIA COLECTIVA DE SU PUEBLO
}

\author{
Semblance of the Lisímaco Chavarría Costa Rican poet: presence in the national letters and in \\ the collective memory of his town
}

Nuria Rodríguez Vargas Instituto de Estudios Latinoamericanos, Universidad Nacional, Costa Rica nuria.rodriguez.vargas@una.cr

Recibido: $26-10-2019$

Aprobado: 29-10-2019

\begin{abstract}
Nuria Rodríguez Vargas es egresada de la Licenciatura en Literatura de la Escuela de Literatura y Ciencias del Lenguaje de la Universidad Nacional. Tiene estudios en Educación, Enseñanza del Español y ELE. Con amplia experiencia laboral en el campo de la Lingüística Aplicada. Magíster en Estudios Latinoamericanos con énfasis en Cultura y Desarrollo. Profesora e investigadora en el Instituto de Estudios Latinoamericanos (IDELA) de la Universidad Nacional.
\end{abstract}

\section{RESUMEN}

La vida del escritor costarricense Lisímaco Chavarría (1878-1913) fue corta, compleja, atormentada y ambivalente. Fue admirado y despreciado, premiado y excluido. Su vida estuvo marcada por las carencias materiales y los dramas. Publicó gran parte de su producción literaria en las revistas de la época en la que vivió. Poeta modernista de fama internacional, pero no siempre reconocido por el canon literario de nuestro país. A más de cien años de su muerte, su presencia sigue viva en la memoria colectiva de su natal San Ramón.

Palabras clave: Lisímaco Chavarría; poeta; modernismo; semblanza; Páginas Ilustradas; canon literario; literatura costarricense

\section{ABSTRACT}

The life of Costa Rican writer Lisímaco Chavarría (1878-1913) was short, complex, trouble, and ambivalent. He was admired and underestimated, awarded and excluded. His life was marked by poverty and drama. He published mainly in journals of his time. He was also an internationally famous modernist poet, not always recognized by the literary canon of his country. One hundred years after his death, his presence remains alive in the communal memory of his native land San Ramón.

Keywords: Lisímaco Chavarría; poet; Modernism; biographical shetch; Páginas Ilustradas; literary canon; Costa Rica literatura 
"El poeta tiene derecho a escribir en las nubes, porque de ellas vino, y a ellas ha de ir, y hablar con ellas. Si su lenguaje no es entendido, dolor para los que no lo entienden".

José Martí

\section{Introducción}

El presente artículo es una semblanza sobre la vida del escritor costarricense Lisímaco Chavarría (1878-1913). Es un recuento de aspectos relacionados con su vida personal, sus publicaciones literarias en las revistas nacionales, premios obtenidos y relaciones con escritores destacados en Costa Rica y en otras latitudes. Además, se describe la presencia y recuerdo del poeta en su natal San Ramón ${ }^{1}$, a través de la prensa local, los centros educativos y en la memoria colectiva de sus pobladores.

Su obra poética destaca por su capacidad de transformar elementos regionales o nacionales para crear construcciones poéticas de carácter universal en el uso del lenguaje, las formas y los temas. Publicó gran parte de su producción literaria en la revista Páginas llustradas desde 1904 hasta 1911. Esta fue un medio que marcó una época, pues da cuenta de la introducción de las diferentes tendencias artísticas, en especial el modernismo, y de los cambios socioeconómicos y culturales.

\section{Lisímaco Chavarría: hombre de letras}

El poema "Vengo del campo" de Lisímaco Chavarría, apareció publicado por primera vez en Páginas Ilustradas en 1907; una de sus estrofas, expresa:

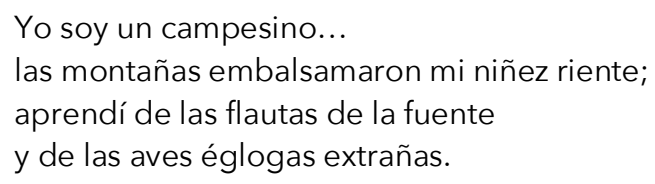

\footnotetext{
${ }^{1}$ San Ramón, cantón número dos de la provincia de Alajuela. Está localizado $65 \mathrm{~km}$ al noroeste de la capital de Costa Rica. Es conocido como "la tierra de los poetas", ya que la poesía ha destacado como actividad cultural desde principios del siglo XX hasta la actualidad. Agradezco a las funcionarias de la Biblioteca Arturo Agüero Chaves de la Sede de Occidente de la Universidad de Costa Rica por su colaboración en la consulta de fuentes bibliográficas.
} 
Los versos anteriores resumen varios aspectos de quién era y qué produjo el poeta ramonense. En su producción son recurrentes las alusiones a la naturaleza, vista como un espacio idealizado de inspiración y crecimiento, al punto que el poema se asume como un elemento más del espacio bucólico.

La producción de Chavarría fue amplia², y sus aportes a la lírica costarricense, valiosos; sin embargo, en poco más de cien años de producción de literatura costarricense, el autor no ha tenido la difusión que se merece, ni su nombre ha sido destacado en los últimos años como uno de los grandes poetas de las letras costarricenses, salvo en las revistas, periódicos y en el imaginario colectivo de la gente de su natal San Ramón.

Así también, interesa destacar la presencia de Lisímaco Chavarría en la revista Páginas llustradas, donde es posible ver su evolución, desde 1905 hasta su muerte en 1913. "Entre 1890 y 1920 aparecen en Costa Rica numerosas publicaciones de carácter literario, de notable orientación modernista, que comparten un espacio con revistas de carácter más político y militante, a veces de adscripción anarquista. Junto a estas, permanecen otras de temática educativa, histórica o legal, que acogen también preocupaciones literarias" (Ovares, 1994, p.13).

En torno a la figura de Chavarría, se han tejido varias historias o anécdotas ligadas a su vida personal; una de las más comunes es la idea de la timidez del poeta, que lo llevó a publicar en sus dos primeras producciones bajo el nombre de su esposa Rosa Corrales. Además, su origen humilde, que lo privó de condiciones básicas de subsistencia, lo que contribuyó al debilitamiento de su salud y su prematura muerte. Por otra parte, en el nivel de las relaciones interpersonales, siempre estuvo rodeado de amistades influyentes y adineradas, quienes en sus primeros años como escritor le tendieron la mano, no así en los últimos días de su vida. Señala Trino Barrantes en un artículo sobre el aniversario 110 de su natalicio: "La solidaridad de sus amigos (¿amigos?) nunca fue orgánica. Muchas veces a su escuálido salario devino una actitud obligada de recurrir al apoyo de ellos, pero los límites de esa amistad se explican por un largo silencio y ausencia consecuente (Rescate, Vol. 6, mayo-junio, 1988, p. 9-10).

\footnotetext{
${ }^{2}$ La producción de Lisímaco Chavarría es la siguiente: Orquídeas (1904), con prólogo de José María (Billo) Zeledón; Nómadas (1906), prologada por Antonio Zambrana; Desde los Andes (1907), con prólogo de Justo A. Facio, esta obra trascendió las fronteras y los poemas de Chavarría se publicaron en prestigiosas revistas del mundo; por ejemplo en France Amerique de París, Cuba de La Habana, América de Nueva York, Expectación Literaria de Alicante, El Comercio de Quito y El Diario de la tarde de Mazatlán; Manojo de guarias (1913), con un prólogo del costarricense Modesto Martínez, sin embargo, tenía ofrecimientos de Rubén Darío, Rodó y Ugarte; y la obra póstuma Palabras de Momia (1919).
} 
Fue un poeta de personalidad complicada; tímido y reservado, pero con un aire que se ha interpretado como altivez. Se ha señalado que Lisímaco Chavarría en su ciudad natal y en la capital, fue admirado pero no querido, por un cierto gesto de antipatía en sus actos y en sus relaciones con las demás personas. Despreciaba las relaciones literarias del mundo costarricense, y debido a su condición humilde era relegado por una gran parte del canon literario. En cuanto a su vida sentimental, nunca tuvo suerte, se casó dos veces, fueron matrimonios fallidos, la primera vez con Rosa Corrales. De sus dos uniones conyugales no le quedaron hijos y con la mujer que más quiso - la que le prestó el nombre a algunos de sus libros, Rosa Corrales- las incomprensiones y los celos los llevaron a la incomunicación total (Chase, 1999, p.11).

Al final de sus días la única mujer que estuvo presente fue Teresa Palma, su madre. Y los únicos amigos, sus hermanos y algunas personas de su comunidad quienes se preocuparon de que pasara sus últimos días con un poco de dignidad, en vez de condiciones infrahumanas. Pero, las dificultades económicas no fueron un obstáculo para que en sus cortos 35 años se consolidara como un gran poeta, no solo por la cantidad de poemas, sino por su calidad.

El 27 de abril de 1994 fue declarado "Benemérito de la Patria" como consta en un artículo de Arturo Alfaro Alfaro, en la revista Entre cantones. Su pueblo nunca lo ha olvidado. Es evidente en los artículos, notas y alusiones a él y su producción en los medios publicitarios del cantón. En la revista Rescate de mayo de 1988, salió un artículo en conmemoración de los 110 años de su nacimiento, escrito por Trino Barrantes quien señala: "Ciertos estudios intelectuales con intenciones claramente estéticas, presentes en algunos trabajos a "favor" de este poeta, antes de rendirle homenaje, buscan resolver su "mea culpa": encubrir el crimen de lesa naturaleza que la oligarquía orquestó contra Lisímaco Chavarría, negándole lo más elemental. Por eso lo elevan a mito, lo materializan en una "Orden Municipal", y lo deslegitiman de su entorno social. Así el poeta es un "abstracto", un referente simbólico, un hombre Patria-Nación, pero nunca un militante de lo cotidiano." (pp. 9-10).

Lo anterior demuestra el descontento de su gente con el largo silencio y la indiferencia por parte de la intelectualidad costarricense hacia un poeta de carácter universal, más que un coplero bucólico como ha sido retratado durante décadas. Los profesionales ramonenses, en particular los educadores, se han encargado de mantener viva la memoria del hijo predilecto de las letras de su cantón. 
Con motivo del aniversario 84 de la muerte del poeta ramonense y Benemérito de la Patria Lisímaco Chavarría, el 27 de agosto, el ayuntamiento local y estudiantes Ilevaron flores a su tumba. La profesora Martha Elida Castro Carvajal, acompañada por alumnos de las escuelas de la periferia de la ciudad, visitaron el cementerio general con flores para el poeta (Alfaro, 1997, p. 9). La visita de los estudiantes de primaria y secundaria de la comunidad es obligatoria.

Cada año, para la fecha de su nacimiento y de su muerte, es recordado en la prensa local. En Historia y geografía del cantón de San Ramón, Trino Echavarría apunta que, hace varios años, la Asociación Ramonense de Maestros le construyó sobre su tumba una pirámide truncada que lleva una cruz inclinada... todos los años, el 27 de agosto, las escuelas, los colegios y la Escuela Normal llevan a sus alumnos cargados de flores a dejarlas sobre la tumba del alto exponente de la cultura ramonense (1966, pp. 50-52).

Néstor Corrales, en la revista Actualidad ramonense, recuerda que la Municipalidad por unanimidad en 1913, acuerda auxiliar al poeta con una modesta suma de dinero y algunos particulares resuelven levantar una suscripción para ayudarlo. Antes, el poeta había tenido que empeñar la famosa Flor de Oro, que la Cultura Nacional como premio a sus esfuerzos poéticos le concedió.

Las producciones de Lisímaco Chavarría datan de 1904, Orquídeas, y en 1906, Nómadas. Las publicó con la ayuda económica de su suegro bajo el nombre de su esposa Rosa Corrales. El poema "El arte" obtuvo el primer premio en la Fiesta del Arte, organizada por el Club Costa Rica en 1905. Esto provocó que cada cónyuge proclamara su paternidad, lo que precipitó el divorcio del hogar Chavarría Corrales. Los intelectuales se dividieron en dos grupos, uno que apoyaba a la poetisa y otro a Chavarría. En 1906, Lisímaco Chavarría confirmó ser el verdadero autor al triunfar en la segunda Fiesta del Arte con los poemas "Al pensador" y "Al trabajo".

Luis Ferrero (1978) en el folleto crítico Lisímaco Chavarría Biografía, sostiene que más tarde se demostrará palmariamente que el verdadero poeta era Lisímaco Chavarría; la señora Corrales había escrito la letra del himno de un partido político y ello fue suficiente prueba. 
Este conflicto de autoría suscitó críticas aún después de su muerte. Sobre el tema señala José Fabio Garnier en un amplio artículo en el que analiza la vida y obra del poeta: "Empezó Chavarría su carrera literaria de un modo humilde: publicó en 1904 sus primeros versos en un volumen titulado Orquídeas, bajo el nombre de su esposa Rosa Corrales; esta modestia fue criticada acerbamente y en verdad lo merecía porque no se comprende por qué el artista quisiese probar los ánimos de la crítica costarricense poniendo como cebo el nombre de su compañera. La crítica fue favorable, si no lo hubiese sido, ¿qué habría hecho el poeta?"3.

Antes de cultivar la parte artística y docente, Chavarría trabajó como peón agrícola en San Pablo de Tarrazú, restaurador de imágenes religiosas en Cartago y practicó el oficio de relojero en Atenas. Por esos años trabó amistad con Justo A. Facio, quien además de su amigo se convirtió en su protector; primero le ayudó a conseguir trabajo como docente y años más tarde un puesto en la Biblioteca Nacional de San José. Posteriormente, conoció a Próspero Calderón, el editor de la revista Páginas Ilustradas, en la que escribiría desde 1905 hasta su muerte en 1913.

Los años de Chavarría en la revista fueron los de su máximo esplendor como poeta, pues en ella publica sus primeros poemas, mejora su producción y es clara su evolución en temas, motivos y técnica. Además, que fue un espacio para nutrirse de las grandes corrientes artísticas del momento. Fueron años de logros y premios, pero también de rencillas intelectuales.

En 1909, la revista organizó los Juegos Florales, donde Chavarría obtuvo la Flor Natural y dos menciones honoríficas, como mencioné anteriormente. Esto representó su consagración como poeta y el reconocimiento de figuras latinoamericanas de renombre como el nicaragüense Rubén Darío, el chileno Manuel Magallanes Moure, el argentino Manuel Ugarte, el venezolano Ismael Urdaneta, y el uruguayo José Enrique Rodó quienes se convirtieron en sus amigos epistolares. Además, gana un certamen latinoamericano organizado por la revista América de Nueva York con su poema "El árbol del sendero". En México se le declara segundo poeta de Hispanoamérica después de Darío. Este triunfo es una verdadera consagración del poeta, pero acrecienta las envidias de ciertos intelectuales hacia el joven campesino ramonense que no había concluido la escuela primaria (González Vásquez, pp.14-18).

\footnotetext{
3 Garnier. Literatura Patria (II). En Letrae, número 46, julio-diciembre de 2009, p. 164. (La referencia fue tomada de la revista Letrae que recuperó el texto original).
} 
Dos años antes, en 1907, había obtenido un puesto de redactor en La Prensa Libre, con la cual había incursionado en el periodismo y fue miembro fundador del Ateneo de Costa Rica, por lo que también había cultivado amistad con grandes intelectuales costarricenses de la época como Joaquín García Monge, Roberto Brenes Mesén, Buenaventura Corrales, Ricardo Fernández Guardia, José María Zeledón, Tomás Povedano, Enrique Echandi y Napoleón Quesada, entre otros.

Con motivo del centésimo aniversario de su natalicio, en el año 1978, la Comisión Nacional de Conmemoraciones Históricas y el Departamento de Patrimonio Histórico del Ministerio de Cultura, Juventud y Deportes publicaron un suplemento en recuerdo del poeta ramonense titulado Lisimaco Chavarría. Biografía y Bibliografía4. Es interesante destacar que en los años posteriores a su muerte, un grupo de admiradores se dedicaron al rescate de anécdotas y detalles de su vida personal y artística. En el prólogo del suplemento mencionado anteriormente, cita Luis Ferrero (1978) a Eliseo Gamboa, Róger Salas García, Trino Echavarría, Carlomagno Araya y Carlos María Jiménez, David Mora, Jesús Córdoba, Estefanía Campos, y Carlos Palma. Entre el grupo, destaca a Trino Echavarría quien recogió y publicó varias cartas en referencia a Chavarría y una interesante carta que dos meses antes de morir envió el poeta a José Joaquín Salas. Transcribo la carta a continuación:

San José 22 de junio de 1913. Señor José Joaquín Salas. San Ramón. Mi buen amigo: Deseaba tener un clarito en mi enfermedad para darle, por su medio, así como a usted también, las gracias más ingenuas, agradecimientos abiertos en el alma como rosas frescas. Cumplo hoy con ese deber que me impone el acto de hidalguía, de generosidad y de nobleza que con esos cultos muchachos de mi tierra, de mi pueblo, han llevado a la práctica para enviarme, como lenitivo saludable, la realidad de una amistad sincera, que ha dado a ese pueblo un lampo más de gloria para la aureola de prestigios en que está rodeado. Aquí en San José ha sido muy celebrada esa nota de recuerdo para con el más humilde de los ramonenses. Hoy más que nunca quedo comprometido a querer más a ese pueblo, mi querido San Ramón, a mis hermanos coterráneos y, cantar a inmortalizar si es posible, en el tapiz de mis pobres versos, la belleza y virtud de las hijas de esos campos, la gentileza de sus hombres y después todos los dones que plugo a Dios arrojar a puñados sobre la esmeralda de esos predios de belleza paradisíaca y eterna. Un saludo cariñoso para usted y todos mis buenos amigos. Su servidor y buen amigo. Lisímaco Chavarría (Echavarría, 1962, p. 2-C).

\footnotetext{
${ }^{4}$ Este documento no viene numerado.
} 
La carta evidencia un cambio en el tono, más suave y condescendiente, talvez por su cercanía con la muerte, que permitió que dejara el estilo mordaz que en ciertas ocasiones utilizó con algunas personas.

A los treinta años de su muerte, en una revista de su pueblo natal, se publica una biografía de Lisímaco Chavarría, pero más que datos concretos y objetivos sobre la vida del artista, utiliza un estilo anecdótico sobre los últimos días de su existencia. Se trata de una crónica, la cual cierra con un poema a su memoria. En esta se cuenta que Chavarría supuestamente, había sido operado en la Casa de Salud de los doctores Uribe y Espinosa en San José, después pidió que lo llevaran a San Ramón, a la casa de su madre y hermanos. Allí, él mismo organizó la construcción de su fosa, la pidió en medio de las tumbas de don Lico Rodríguez, su maestro de cerámica, y su amigo don Pío Quinto Quesada. "Lisímaco volviéndose a su mamá, le dijo: qué bien voy a estar en medio de dos amigos" (Paniagua, 1943, pp. 66-67).

Años más tarde, otro de sus seguidores, Eliseo Gamboa, también hijo de San Ramón, en su condición de diputado, tuvo la iniciativa de destinar una cantidad de dinero específica para publicar una nueva recopilación que tituló Poesía.

Artículo 1 - Destínase la suma de dos mil colones $(2,000.00)$ para editar la obra literaria de Lisímaco Chavarría, y con dicha cantidad amplíase el presupuesto vigente de la Cartera de Educación Pública.

Artículo 2 - La referida Cartera nombrará una comisión compuesta de tres personas para que proceda a efectuar una selección de los trabajos de dicho autor y disponga lo concerniente a la publicación del tomo o tomos correspondientes. (Chavarría, $1940)^{6}$.

El tomo se terminó de imprimir en la Imprenta Nacional, en noviembre de 1940, prologado por tres grandes intelectuales de la época: Rogelio Sotela, Julián Marchena y Jorge Sáurez F., quienes eleccionaron los siguientes poemas con imágenes nacionales, por ejemplo: "Manojo de Guarias", "Pudreorejas", "El árbol solitario", "Las Quemas", "Las Guacamayas", "El Zopilote", "En el trapiche, Bodas Campestres", y otros imágenes más universales, por ejemplo: "Como los faunos", "El Moisés de Buonarrotti", "A la reina de la fiesta". Los escritores indican que el comienzo literario de Lisímaco Chavarría coincidió con el esplendor del modernismo y que es visible la influencia que ejercen sobre él los creadores de

\footnotetext{
${ }^{5}$ La crónica completa es narrada por Rafael Lino Paniagua.

6 La cita corresponde al prólogo titulado, Explicación y Elogio, y está firmado por Rogelio Sotela, Julián Marchena y Jorge Sáurez. Estas páginas no incluyen numeración.
} 
esa escuela Nervo, Valencia y Darío. Destacan la belleza de sus obras: "...Nosotros como compiladores, hemos querido ser más "selectores", para mostrar al país y a la América estas composiciones en que va la gloria de este humilde y hondo poeta costarricense" (Chavarría, 1940).

Por otra parte, sostienen los compiladores que en su último tiempo había comenzado a trabajar la literatura regional, aunque no a la manera de Aquileo J. Echeverría, pero que había cimentado el folclore costarricense. Además, se refieren a las publicaciones hechas de Chavarría en el extranjero, "Los costarricenses vimos algo que no por corriente, deja de ser doloroso: el poeta nos venía avalorado de afuera, nos lo habían hecho en el exterior. De este modo tuvo la suerte de ser aplaudido por Darío, por Rodó, por Vicente Medina, y por tantos con quienes mantenía correspondencia constante" (Chavarría y otros).

No ha sido el poeta ramonense el objeto de estudio más solicitado por estudiantes universitarios y académicos. Muchas veces mencionado en estudios sobre literatura costarricenses, pero sin adentrarse en su producción; sino en su condición de campesino poeta. La primera tesis sobre él, hecha por María Isabel Araya Coronado, data de 1950. En general, este trabajo hace un recorrido por su vida, información personal y detalles anecdóticos más que un análisis sobre su producción e influencias. El trabajo siempre destaca la característica de hombre humilde y campesino de escasos recursos económicos. Hace hincapié en que el poeta no tenía estudios formales, no terminó la escuela primaria, las lecturas y la intelectualidad vinieron producto de su disciplina autodidacta, destaca el cariño, aprecio y admiración de la gente de su pueblo. Resalta las características personales que lo elevan a una condición de ser superior casi comparable con un Santo: "Incapaz de abusar del alcohol, de la mesa, de los amores fáciles. Era un sujeto puro, de una pureza atrayente" (Araya Coronado, 1950, p. 22).

Araya Coronado destaca el amor por su pueblo y su gente, por la patria y sus paisajes y, claro, por su familia. Reproduce una carta que le envió Chavarría a Ramón Zelaya solicitándole trabajo para su hermano, pocos meses antes de morir. Es claro que el roce del poeta ramonense con gente de renombre en la época fue aprovechado en parte, primero para desarrollarse como artista y acceder a espacios del arte y la cultura que solamente estaban reservados para la gente de clase alta, de la oligarquía, pero también hacia el final de sus días para tratar de ayudar a su familia como se ve en la siguiente carta: 


\begin{abstract}
Al Señor
Doctor Ramón Zelaya

llustre y buen amigo;

A usted que generosamente nunca se ha favorecerme, me dirijo ahora tras un servicio que para usted es fácil concederme y para mí de gran importancia.

Mi hermano Eladio Chavarría, portador de ésta, desea por su medio y yo también lo que deseo que lo coloque en la United. Él sabe bastante inglés hablado, es honrado a carta cabal y laborioso, y usted como abogado de aquella compañía tal vez podría colocarlo de algo, favor que nunca acabaríamos de pagarle.

Espero que usted no me escatimará esta vez más sus buenos oficios e influencia. Lo saluda con respeto

Lisímaco Chavarría

San José, 28 de febrero de 1913.

Araya Coronado, 1950, pp. 24-25).
\end{abstract}

La investigadora hace una sentida disertación sobre la relación de Lisímaco Chavarría y su madre Teresa Palma. Relata cómo ella estuvo presente cuando fue llevado al cementerio de San Ramón a ver su propia fosa, pocos días antes de fallecer. Cuenta que la víspera de morir le dijo a su madre que le llevara el estuche con la Flor Natural y dijo: "Tómela usted; hoy es mi partida: madre mía querida, las lágrimas sirven a veces para desahogar nuestros pesares, pero la de los seres queridos nos entristece y nos hace sufrir; sabe que voy a morir y por eso llora, pues no llore si quiere que muera feliz ¿Me lo promete?" (Araya Coronado, 1950, p 37).

La obra de Chavarría fue más apreciada en el extranjero que en Costa Rica; una muestra es la cordial amistad y contacto que mantuvo con escritores e intelectuales de otros países. En el prólogo ${ }^{7}$ del folleto de Luis Ferrero (1978) se encuentran algunos datos que respaldan la afirmación anterior, por ejemplo: el artista cubano Uzcátegui hizo una caricatura del poeta ramonense, la cual se exhibió en los salones del Ateneo cubano. Además, Ignacio Trullás Arlet traduce al catalán el poema "Yo juera su novia", el peruano Ricardo Palma le envió un libro con una afectuosa dedicatoria y un año después de su muerte, el conde Maurice de Périgny traduce al francés cinco poemas de Lisímaco y los reúne en un volumen con cuentos de Ricardo Fernández Guardia y poemas de Aquileo J. Echeverría.

Murió Lisímaco Chavarría un 27 de agosto de 1913 en su natal San Ramón a la corta edad de 35 años. "Su fama como inspirado vate. No solo llenó de guirnaldas de gloria su humilde San Ramón, sino a Costa Rica y más allá de sus

\footnotetext{
${ }^{7}$ El prólogo del folleto de Luis Ferrero (1978) no cuenta con numeración en las páginas.
} 
fronteras. La Municipalidad de su pueblo le rinde Guardia de Honor en el Palacio Municipal. Su tumba se cubre de rosas, las rosas que con amor él quería y su recuerdo será eterno en los versos que pulsó su lira" (Quesada, 1999, p. 104).

Nueve meses antes de morir, en noviembre de 1912, le había escrito a Modesto Martínez para que le prologara el libro en el que estaba trabajando, el cual era sobre temas costarricenses. Es interesante destacar que Rubén Darío, Santiago Argüello, José Enrique Rodó o Manuel Ugarte pudieron haber prologado el libro; sin embargo, prefirió al periodista costarricense (Chase, 1975, p. 19).

En el libro Poesías escogidas de Lisímaco Chavarría, incluye Alfonso Chase el intercambio epistolar. A continuación un extracto literal de la carta de solicitud que envió el poeta ramonense a Modesto Martínez (Chase, 1975, pp. 188-190):

"Señor don Modesto Martínez.

Caro amigo: Efectivamente, como usted lo afirma, hace días hablamos de una nueva obra mía que tengo lista sobre asuntos puramente costarriqueños.

Y aunque Rubén Darío, Argüello, Rodó (José Enrique), y Ugarte me han ofrecido prologar obras mías (perdóneme mi vanidad), lo prefiero antes que a aquellos maestros, a Ud. Las razones huelgan; Ud es costarricense, conoce nuestras costumbres y nuestras bellezas nativas; las pastoras, las guarias que matizan las vegas del riachuelo, las guacamayas que se disparan como dardos de colores,

"del arco de esmeralda de los montes."

Usted ha visto las cogedoras de café de retorno de la hacienda, al bohío alegre del villorio; los turnos en que el coplero popular lanza al público de campesinos bombas como ésta:

"Decís que no me querés porque no tengo bigote, mañana me lo verés de plumas de zopilote."

Poco tiempo después, Martínez le responde, le agradece la solicitud y acepta la propuesta de prologar su nuevo libro. Un extracto de la respuesta dice: "Su obra le dará fama por allá en el extranjero,- aquí no- ya puedo suponerlo...Termine, pues, su libro, y ya veremos la manera de editarlo, que será el gran problema para Ud., que no es rico. Estoy seguro de que habrá muchas gentes dispuestas a contribuir para la edición, porque ambos parece que vivimos permanentemente aplastados por la "Losa de los sueños", hay una pequeña minoría que sueña aún bajo el peso de la losa misma, y que por darse el placer de saborear producciones de arte nacional puro, son capaces de desprenderse de una pequeña suma. Ya le enviaré una lista de los que están dispuestos a contribuir" (Chase, 1975, p. 190). 
En 1913, mediante publicación póstuma, salió a la luz el libro Manojo de Guarias, con prólogo de Modesto Martínez. Según Alfonso Chase, el libro no se publicó como Chavarría lo hubiera deseado. Si bien es cierto, el poeta ramonense mantenía una fuerte relación epistolar con grandes modernistas hispanoamericanos, también tenía correspondencia con el poeta costumbrista murciano Vicente Medina, a quien Chase califica de "mediocre poeta campesino" y lo responsabiliza de haber motivado al costarricense a escribir poemas de carácter campesino. "Ya para esa época el espíritu de Lisímaco Chavarría estaba lleno de la imaginería modernista y no podía llegarse con soltura al indigenismo o al popularismo, que fueron formas por las cuales se expresó esa escuela, sobre todo en momentos de declinación" (Chase, 1975, pp. 19-20).

A los cien años de la muerte de Lisímaco Chavarría, en 2013, se publicó una investigación profunda, extensa y detallada, llevada a cabo por el ramonense Francisco Rodríguez Cascante. Hace una categórica compilación de toda su obra: poemas, textos narrativos y ensayos publicados en libros y en otros medios; acompañados de una completa biografía y un estudio literario crítico. "A cien años de su muerte es hora de ir más allá de la leyenda para distinguir al intelectual que junto con Roberto Brenes Mesén y José María Zeledón renovaron la literatura costarricense a inicios del siglo XX, al recepcionar al modernismo hispanoamericano y las corrientes ácratas, cuando se estaban dibujando los primeros trazos de la nación costarricense" (Rodríguez Cascante, 2013, p.3).

Por otra parte, en año 2013, San Ramón de Alajuela estuvo colmado de actividades en memoria de Chavarría. Se contó con la colaboración de instituciones como la Universidad de Costa Rica, Sede de Occidente, la Municipalidad de San Ramón, el Museo José Figueres Ferrer y organizaciones civiles. Así, la comunidad tuvo la oportunidad de asistir a recitales de poesía, simposios, una bienal pictórica y escultórica, una edición de "juegos florales" en todas las disciplinas, productos culturales: poemarios, calendarios conmemorativos y ediciones críticas de sus obras.

Entrevistado por el Semanario Universidad, el académico Francisco Rodríguez Cascante resaltó: "Servirá para saldar una deuda histórica de la sociedad costarricense, pues, a pesar de ser Chavarría uno de los más reconocidos exponentes de la poesía nacional, las ediciones originales de sus libros son casi imposibles de conseguir, son documentos que se consideran antiguos o raros" (Semanario Universidad, 16 de enero 16, 2013). 


\section{Lisímaco Chavarría y Páginas Ilustradas como principal medio de difusión}

Durante el siglo XIX, nuestro país estaba comenzando a consolidarse como nación y todavía a principios del siglo XX el arte plástico apenas iniciaba su desarrollo. La población no tenía acceso a consumo o difusión de obras salvo las personas que tenían la oportunidad de viajar a Europa o los Estados Unidos y aprender allí sobre las nuevas tendencias artísticas.

Las revistas tenían la función no solo de informar, sino de crear espacios de discusión, de polémica y de difusión de las diferentes manifestaciones o tendencias estéticas. Es frecuente encontrar obras de autores europeos y latinoamericanos ya consolidados, o de escritores costarricenses en formación, como el caso de Lisímaco Chavaría, quien realiza muchas de sus primeras publicaciones en la revista Páginas llustradas.

Esta publicación fue uno de los medios escritos utilizado por los escritores costarricenses de principio del siglo XX para publicar sus obras. La revista estuvo vigente durante el período del estado liberal. Las políticas liberales generaron cambios económicos que propiciaron cambios sociales y culturales, entre ellos, la adopción de corrientes artísticas en tendencia como el modernismo.

La revista Páginas llustradas funcionó como medio de difusión de la naciente literatura costarricense. Empezó durante un contexto político marcado por las políticas liberales, las cuales habían generado un cambio sociocultural importante, al pasar de lo meramente rural a lo urbano. "El tardío despliegue historiográfico y literario fue condicionado, por la invención de la nación. Este proceso, iniciado después de 1870, fue lento y escabroso, y supuso, aparte de la fundación de instituciones (museos, teatro, colegios, bibliotecas), la emisión de monedas, el ascenso de un panteón de héroes, la construcción de estatuas y la práctica de un conjunto variado de tradiciones nuevas, especialmente de la fiesta cívica en torno a un evento o a un héroe." (Molina, 2004, pp. 136-137).

En 1904, aparecieron publicaciones de algunos poemas en Páginas llustradas, bajo la autoría de Rosa Corrales de Chavaría, "Fantasías bíblicas" (Páginas Ilustradas, V. 1(15) (1904) pp.227-228) y "Exhalaciones" (Páginas Ilustradas, V1 (17) (1904) 270). 
Es el año de la publicación del primer poemario Orquídeas. En junio de ese año, Ramón Zelaya, intelectual de la época, publica un artículo en referencia a la nueva poetisa Rosa Corrales, sus obras y la reciente publicación de su primer poemario. El artículo hace una reflexión sobre lo que se está escribiendo en ese momento, en qué o en quiénes se están inspirando los artistas, y en las influencias y lecturas sobre cultura universal que deben tener quienes escriben y que deben verse reflejadas en sus producciones. "No obstante que es latinoamericana, esta letrada se presenta sin petulancias torrentosas ni vanidades bullangueras. En ninguna de sus composiciones -cosa rara- se encuentra la afirmación de que es portadora de una Poesía nueva o de un Arte desconocido" (Páginas llustradas, 1904, pp. 338-339).

En posteriores números, la revista seguirá publicando obras de Rosa de Chavarría, por ejemplo, "A moda de estatua" en la revista número 38, "Nadita" en la número 40, "A Kloto" en la número 41 y en el siguiente número, un texto que titula "Una broma" y es dedicado a Próspero Calderón, es una larga canción de cuna y la fecha de creación está indicada como en 1901. Esta última publicación corresponde al mes de noviembre de 1904, y no volverá a aparecer nada más con el nombre de Rosa de Chavarría en los tomos y números siguientes. Es hasta julio de 1905 que apareció por primera vez publicado un poema bajo el nombre de Lisímaco Chavarría. Desde ese momento, se seguirán publicando sus poemas casi en forma sucesiva hasta su muerte.

En la revista número 57, correspondiente al mes de julio de 1905 en la página 911, se encuentra el poema titulado "En el destierro"8:

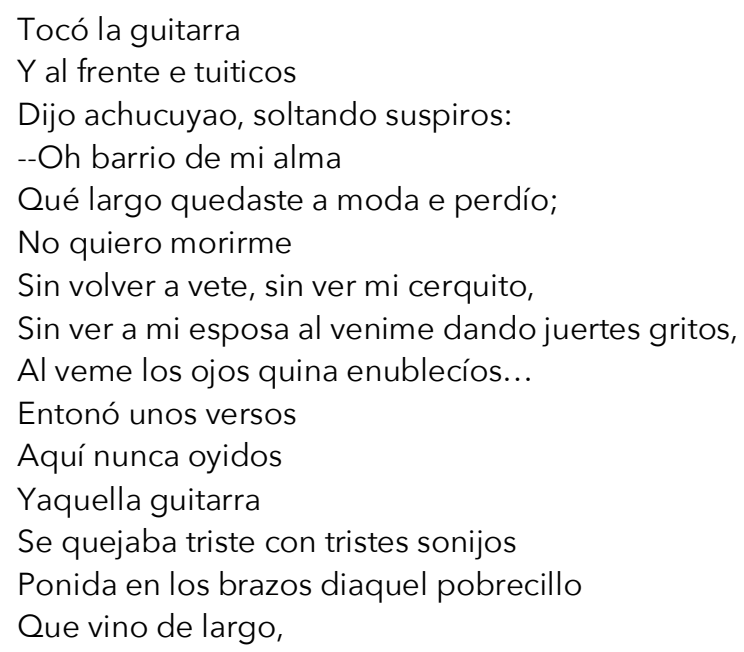

8 Algunos de poemas de Chavarría publicados en Páginas Ilustradas tienen algunas diferencias en la
ortografía, en publicaciones posteriores se hicieron algunos cambios. Este mantiene la forma original. 


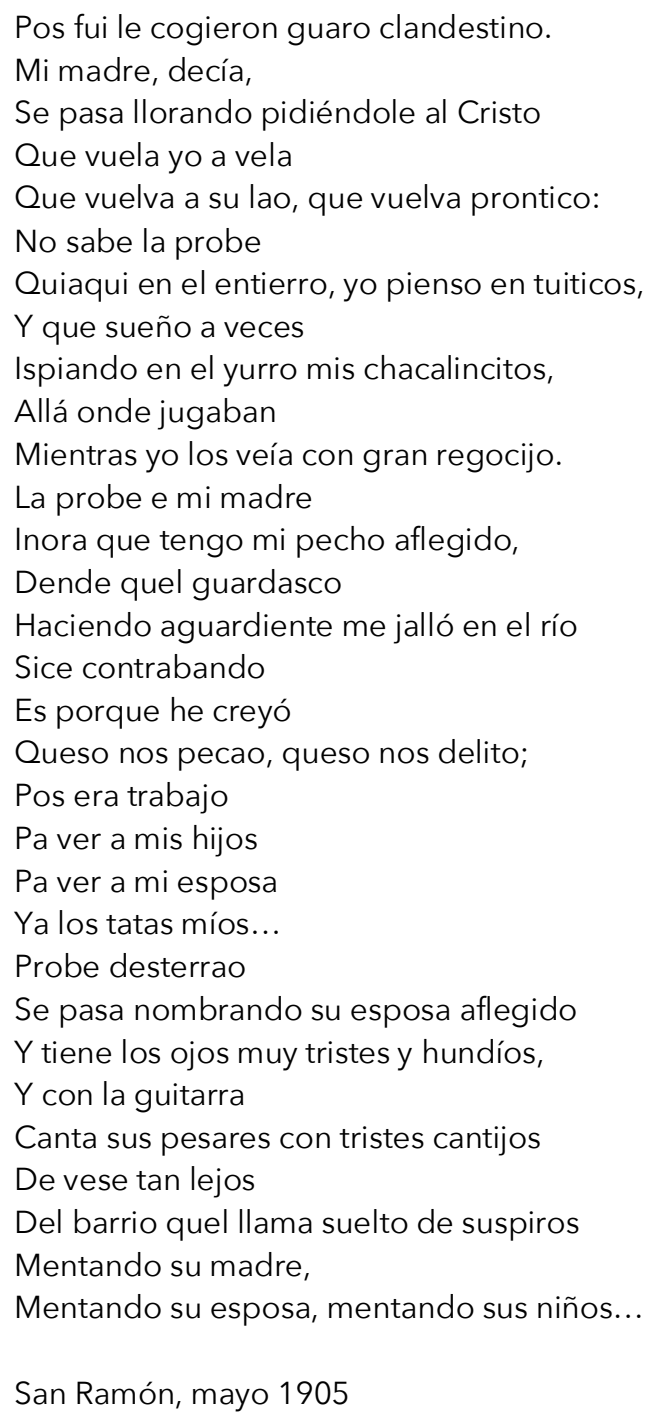

El poema anterior no se acerca al estilo de la mayoría de los poemas escritos por Chavarría. Es un intento de poema costumbrista donde trata de reproducir literalmente el habla campesina costarricense y algunos aspectos relacionados con la vida del campo, pero más bien parece que trata de emular una de las concherías de Aquileo Echeverría, que fueron escritas en el mismo año.

En el siguiente número de la revista, Páginas Ilustradas V. II, 1905, número 58, publica el poema "La Güerta", el cual tiene las mismas características del poema anterior, pero en este el motivo de la naturaleza es fuerte, los colores, los aromas, los vegetales, los pájaros. Hay una idealización del campo como espacio de tranquilidad y pureza. Por lo tanto, hay una oposición espacial, retrata la ciudad como un lugar donde "cunden las maldades y los vicios". 


\author{
Vamos esta tarde \\ $\mathrm{Pa}$ enseñarte el campo que te he prometío \\ Pa enseñarte el campo \\ Lleno de cojombros, lleno de pepinos, \\ Y los frijolares que están en purismo, \\ Yaquellas socolas de maíz floreció... \\ Pegada del yurro \\ Haré la vivienda pa vivir juntitos \\ Onde los yureses fabrican sus nidos, \\ Onde por las tarde \\ Cantan los yigüirros \\ Pa llamar las aguas, con sus enredijos. \\ Vamos a la güerta \\ Onde mis sudores quedaron vertíos \\ En aquellas eras que dan regocijo, \\ En aquellas eran que me aniega el río \\ Cuando nuay silampas, en los veranillos, \\ ¿Decís quiun concierto \\ Te lleva a ausentarte diaquí del istrito? \\ En la siudá cunden maldades y vicios; \\ Allá Margarita, \\ Siendo tan cristiana, cogió mal camino, \\ $Y$ hoy naide la quiere, \\ Ni ya la apresean, ni tiene aquí amigos... \\ No pensés en eso, pos es desatino... \\ Aquí tenés padres, querés, tuitico, \\ Y también el campo \\ Que si nos casamos yo te lo prometío, \\ Onde nuay maldades \\ Ni tampoco lujos que cunden de vicios, \\ $Y$ aunque samos pobes \\ Seremos dichosos, quini los yigüirros \\ Que llaman las aguas con sus enredijos, \\ Quina aquellos mozos \\ Lucieron el rancho cerquita del río... \\ No dejés tu barrio con tantos amigos; \\ Aquí tenés padres, \\ Querés, tuitico \\ Y también la huerta que te he prometío...
}

San Ramón 1905.

Después de estos dos poemas de corte costumbrista, en la edición número 60 correspondiente al 16 de septiembre de 1905, abre la revista con el poema "El Moisés de Buonarrotti" con dedicatoria a Páginas llustradas. 


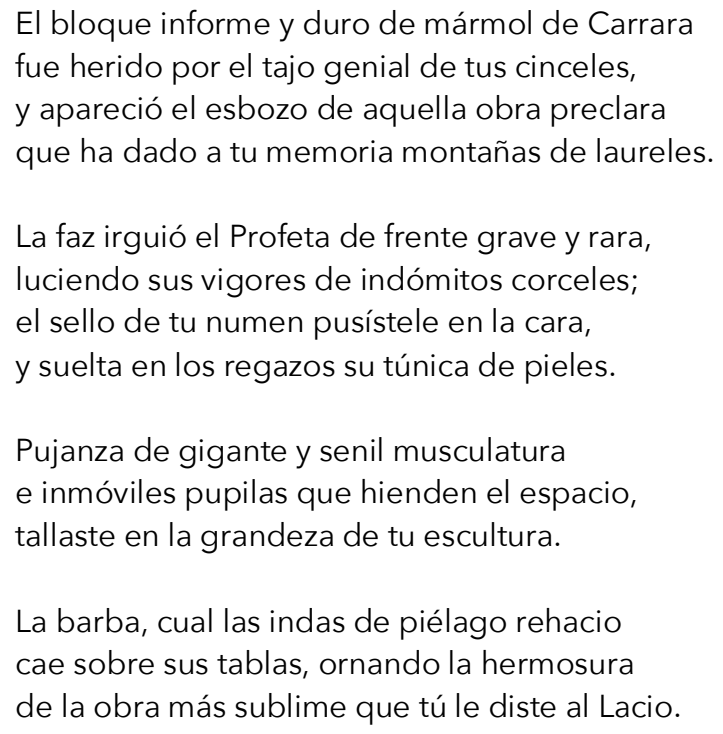

Si bien las obras poéticas de Lisímaco Chavarría fueron publicadas por imprentas de la época como la Nacional, Alsina y Moderna, solo para citar algunas, es en la revista Páginas llustradas donde alcanzaron mayor difusión. Una de ellas fue la veneración de la lectura, durante la última mitad del siglo XIX e inicios del $X X$, esto asociado a la ideología del progreso (Molina, 1995, p. 202) $y$, en parte, a causa de la inmigración de comerciantes europeos, muchos de los cuales se dedicaron al negocio de los libros: librerías, imprentas, litografías, estudios fotográficos, entre otros.

Los comerciantes e intelectuales venidos del extranjero, no solo trajeron los medios técnicos de la producción y las estrategias de comercialización de libros y revistas, sino también, información sobre las tendencias artísticas del momento y la posibilidad del intercambio de conocimientos, ideas y obras artísticas. Aunque la revista Páginas Ilustradas pudo tener influjo de varias corrientes artísticas la predominante era la corriente modernista, la cual se evidencia desde el formato de la revista hasta los temas y escritores que publicaban en ella.

En el caso de Lisímaco Chavarría, gracias al roce intelectual y artístico de Páginas Ilustradas con revistas y escritores extranjeros, muchas de sus obras fueron reproducidas en revistas latinoamericanas, europeas y estadounidenses. Además del contacto con escritores latinoamericanos y españoles, los cuales apreciaban y analizaban su producción poética, de ahí el carácter continental del poeta, talvez en muchas ocasiones no reconocido. 
La producción poética de Chavaría no siempre se ha considerado modernista por parte de la crítica literaria; se le ha tachado de romanticista tardío o de premodernista. En muchos de los casos porque los espacios geográficos están relacionados con la vida rural y campestre, asociados normalmente al costumbrismo por algunos estudiosos.

Carlos Rafael Duverrán califica la producción de Chvarría como premodernista con rasgos románticos. "La principal condición de la poesía de Lisímaco es la espontánea frescura. Con ella expresa una concepción poética de nuestros campos - que es su mundo- y un sentimiento trágico de vivir - que es su destinovolcado sobre la naturaleza." (1973, p. 25). En esa misma década, Alberto Baeza Flores ubica a Lisímaco Chavarría dentro de la generación de modernistas. Sobre su obra señala, al igual que Bonilla y Duverrán, que hay rezagos románticos y que su sensibilidad está asociada al paisaje rural. Dice que lo mejor de su obra lírica es la comunicación y lo negativo fue el haberse entregado a una "moda" en referencia al modernismo. "Chavarría cae, a veces, en un Modernismo de segunda clase, cuando nos habla de ese "paje floral de los abriles" o de esos collares de ópalos", pero, de pronto, nos habla de una sien de rosa" y todo parece transfigurado por la poesía" (1978, p. 108).

Trazar una definición del modernismo es una tarea complicada y riesgosa, especialmente en el ámbito latinoamericano, pues esta corriente artística tuvo muchas influencias en sus orígenes, tanto europeas como de nuestro continente. La incorporación de esos ambientes rurales era parte del exotismo que promulgaba esta corriente. Sin embargo, sobre los orígenes, representantes, clasificaciones y las características del modernismo no se profundizará ahora pues merecen un análisis detallado y un artículo y un estudio aparte, que se abocarán a sus implicaciones históricas, ideológicas y socioculturales.

Señalaré para efectos de este artículo, a los estudiosos costarricenses quienes han resaltado características modernistas en la obra de Chavarría. Dos de sus poemas: "Laocoonte", y "La Magdalena de Henner", se destacan por la presencia del esteticismo y la percepción de la vida en semejanza con el arte (paisajes, cuadros, esculturas, colores y formas), la importancia del léxico cosmopolita, apartado del coloquialismo y del regionalismo; el sensorialismo y también destacan los motivos referidos al arte y la defensa de la hispanidad y el americanismo, claro, sin desprenderse de la atmósfera idealizante de procedencia esteticista (Monge, 1992, p, 19). 
El siguiente poema, "La Magdalena de Henner", apareció publicado en Páginas Ilustradas, IV, 138, 1907, p 2007.

\author{
Destrenzada su blonda cabellera \\ y con la faz hundida entre las manos, \\ echa al olvido sus placeres vanos \\ y gime compungida la ramera. \\ Desnudo el cuerpo, que triunfado hubiera \\ de las diosas y mármoles paganos, \\ ostenta sus contornos soberanos \\ de la Venus de Milo a la manera. \\ Así del gran pintor, la pecadora \\ que mereció el perdón del Nazareno \\ arrodillada su pasado llora... \\ Sobre su torso, de belleza lleno, \\ una escala de luz, como una aurora, \\ desciende hecha caricia hasta su seno.
}

En relación con el tema del americanismo, señala Margarita Rojas que el modernismo asumió el canto de la naturaleza americana o nacional y se alejó de la descripción realista para insertarla en un sistema de signos culturales y describirla como objeto de arte. Sobre la obra de Chavarría, se concentra en Manojo de guarias y analiza que por tratar una temática autóctona, cumplió con la preferencia del público y críticos hacia el arte que escogían asuntos y escenarios nacionales. "Al situarse el libro de Chavarría dentro de esta forma de escribir, pese a tratar un tema nacional, adquirió rango de "literatura". Así, logró superar de manera eficaz para el lector tico la tradicional oposición entre lo nacional y lo extranjero. Por esto, su autor se consagró como poeta nacional." ((Rojas, 1995, pp. 64-65).

En el caso de América Latina y su producción modernista, en algunas obras es posible encontrar expresiones híbridas, temas y motivos indígenas e influencias foráneas lo que no les quita autenticidad. El proceso evolutivo del modernismo coincidió con cambios ideológicos de nivel planetario como la industrialización, el positivismo filosófico, el cientificismo, el capitalismo, el marxismo incipiente, la lucha de clases y el papel de las burguesías. Estas se vieron obligadas a someterse a los imperialismos. En esta coyuntura surge "la pequeña burguesía", producto de la modernización de la enseñanza, lo cual adquirió mayor preparación cultural y comenzó a ocupar cargos en la administración pública y el ejército, así como intelectuales, escritores, artistas, educadores y periodistas. 
Este aspecto es necesario para entender en los análisis posteriores del trabajo los temas de fondo y el compromiso de los escritores modernistas nuestros. Señala Yerko Moretic que la burguesía otorgó la tarea literaria a la "pequeña burguesía" y los nuevos escritores provenientes de estratos medios, quienes reciben el quehacer literario como labor privilegiada. Estos escritores son portavoces ideológicos de una burguesía que ya no es pujante, optimista, sino truncada, impotente y temerosa del imperialismo agresivo y el proletariado insurgente. "Por primera vez en América Hispánica, la labor literaria parece alcanzar una autonomía relativa con respecto a su condicionamiento social y político. Por primera vez los escritores no cargan la responsabilidad clara y directa de ser los voceros de los intelectuales nacionales o de su clase. Por primera vez, los intelectuales ideológicamente débiles, tienden a mirar hacia sí mismos más que hacia su alrededor (Moretic, 1986, pp. 59-60).

Con respecto al modernismo latinoamericano, asumió diversas codificaciones estéticas no solo de una manera estática o imitativa sino, muchas veces, de forma constructiva, generando así artefactos híbridos de profundos acentos americanistas (Rodríguez Cascante, 2013, p. 88).

En el siguiente poema "Desde los Andes" parte de lo nuestro-americano, la geografía y su exotismo natural, constituyen un homenaje al continente en estrecho vínculo con la naturaleza. Se publicó inicialmente en Páginas llustradas, a la que fue dedicado, Año II, N. 69, 19 de noviembre de 1905, en la página 1099:

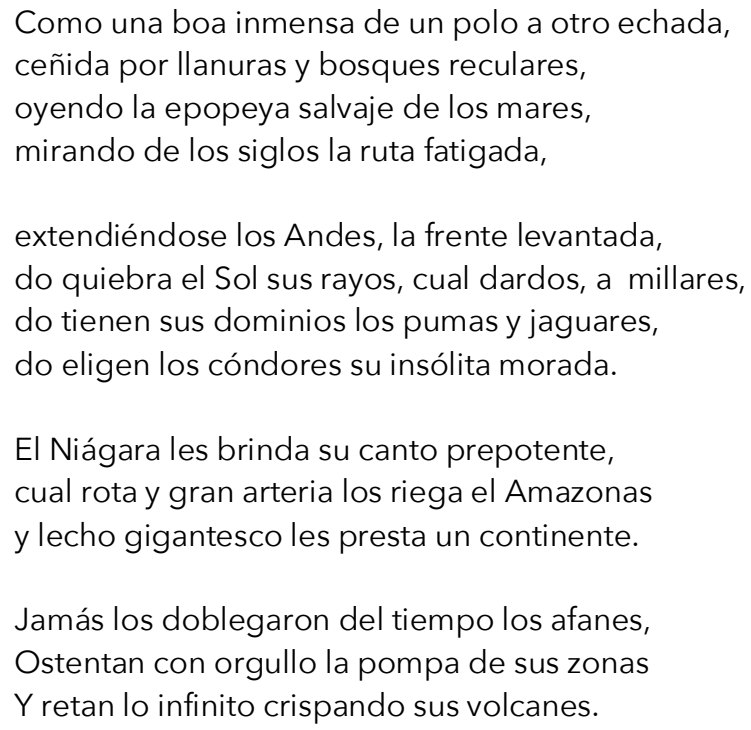


Concluye el investigador ramonense Francisco Rodríguez Cascante que los textos de Lisímaco Chavarría no ofrecen un modernismo de segunda clase ni un lenguaje atrofiado por falta de recursos expresivos, así como tampoco se debe valorar su escritura por provenir de un pobre hijo de San Ramón. Y continúa señalando que su producción poética constituye una lectura crítica y apropiativa del modernismo hispanoamericano y de la polémica generada en su época sobre la literatura nacional (2013, p. 88).

\section{A manera de conclusión}

Lisímaco Chavarría fue uno de los primeros poetas modernistas de nuestro país, por los temas que trataba en su producción, además del estilo, vocabulario, símbolos y figuras literarias y de construcción. Su producción fue de alcance internacional; así lo demuestran artículos, intercambios epistolares con grandes escritores latinoamericanos y españoles de la época, y crítica literaria de ese momento que lo reconocían como un digno representante del modernismo. La madurez de su obra fue frenada por la fatalidad, pues perdió la vida en el apogeo de su producción lírica. Sin embargo, sus motivos literarios y estilo parecen haber influido en la producción de dos poetas ramonenses posteriores: Carlomagno Araya y Rafael Estrada en el período comprendido entre 1915 y 1930.

El canon literario costarricense de la primera mitad del siglo XX no lo reconoció como poeta modernista, sino como un poeta costumbrista, asociado a la vida rural. Sin embargo, en las décadas siguientes esa percepción comenzó a cambiar, fue incluido como modernista en antologías de literatura costarricense, algunos de sus poemas se incluyeron en los programas de secundaria del Ministerio de Educación Pública (MEP), y fue objeto de investigación académica.

La memoria colectiva de su natal San Ramón nunca lo ha abandonado. Su presencia espiritual está materializada en cada rincón de la ciudad, en las escuelas, en los parques, en los museos y en la universidad. Pero lo más importante, en el corazón y la memoria de los habitantes, quienes conocen su vida, su obra y lo recuerdan con orgullo en las conversaciones cotidianas, en las actividades culturales y en las publicaciones periodísticas del cantón.

La revista Páginas llustradas constituyó un medio de difusión artístico de considerable importancia en la primera década del siglo XX. Se pretendió 
relacionar la obra del poeta Lisímaco Chavarría con la revista y las manifestaciones literarias que pudieron haber influido en la producción lírica de años posteriores. La revista se publicó en una época de cambio, hacia un nuevo siglo, con movimientos artísticos superados y otros que se consolidaban con fuerza como el caso del modernismo.

Es clara la importancia y contribución de la revista Páginas Ilustradas al desarrollo de las letras y cultura costarricenses. Fue un medio desde el cual muchos nacientes escritores costarricenses de la época pudieron darse a conocer. En la revista se publicaban poemas, cuentos, crónicas y obras dramáticas de diferentes movimientos literarios. Por ejemplo, se podían encontrar poemas modernistas de grandes escritores costarricenses como Roberto Brenes Mesén y Justo A. Facio, lo mismo que obras costumbristas de Aquileo J. Echeverría o los folletines románticos de Manuel Argüello Mora. Sin embargo, en general, la revista tiene un marcado aire modernista. Y el caso de Lisímaco Chavarría es un ejemplo destacado, ya que su obra poética fue publicada en la revista en todas las ediciones desde 1904 hasta 1911.

\section{BIBLIOGRAFÍA}

Alfaro, A. (1997). "Flores para el poeta". Entre cantones, Vol. 8, N5, p. 9.

Apuntes históricos y crónicas de la ciudad de San Ramón en su centenario (1943). Imprenta La Tribuna.

Araya, M. I. (1950). Tesis. Biografía y obra de Lisímaco Chavarría. San José: Universidad de Costa Rica.

Baeza, A. (1978). Evolución de la poesía costarricense. San José: Editorial Costa Rica.

Barrantes, T. (1988). 110 Aniversario de Lisímaco Chavarría. Rescate, Vol. 6, mayo-junio, p. 9.

Bonilla, A. (1967). Historia de la literatura costarricense. San José: Editorial Costa Rica.

Chacón, A. y otros (2007). Diccionario de literatura costarricense. San José: Editorial Costa Rica. 
Chase, A. (1975). Poesías escogidas de Lisímaco Chavarría. San José: Editorial Costa Rica.

Chavarría, L. (1999). Poesías escogidas. Prólogo de Alfonso Chase. San José: Editorial Costa Rica.

Chavarría, L. (1978). Biografía y bibliografía. San José: Comisión Nacional de Conmemoraciones Históricas y Departamento de Cultura, Juventud y Deportes.

Chavarría, L. (1940). Poesías. San José: Imprenta Nacional.

Corrales, N. (s.a.). Ilustres figuras ramonenses. Actualidad ramonense, 5 (2) 4-5.

Duverrán, C. (1973). Poesía contemporánea de Costa Rica. San José: Editorial Costa Rica.

Echavarría, T. (1966). Historia y geografía del cantón de San Ramón. San José: Imprenta Nacional.

Echavarría, T. (1962). Apuntes sobre la vida de Lisímaco Chavarría. En La Prensa Libre, 11 de setiembre, p 2-C.

Ferrero, L. (1978). Lisímaco Chavarría Biografía. San José: Ministerio de Cultura Juventud y Deportes.

Garnier, J. F. Literatura Patria (II). Letrae, N 46, julio-diciembre de 2009, p. 164.

González, F. (s.a.). El arte en el alma. Revista Fronteras, N 13, pp. 14. 18.

Molina, I. (2004). La estela de la pluma. Heredia: Editorial de la Universidad Nacional.

Molina, I. (1995). El que quiera divertirse. Libros y sociedad en Costa Rica (17501914). Heredia: Editorial de la Universidad Nacional.

Monge, C. F. (1992). Antología crítica de la poesía de Costa Rica. San José: Editorial de la Universidad de Costa Rica. 
Moretic, Y. (1986). Acerca de las raíces ideológicas del modernismo hispanoamericano. Lily Litvak, El Modernismo. Madrid: Editorial Taurus.

Ovares, F. (1994). Literatura de Kiosco. Heredia: Editorial de la Universidad Nacional.

Páginas llustradas (todas las ediciones 1904-1911). San José: Ediciones de Próspero Calderón.

Quesada, A. (1999). Perfil de las letras ramonenses. San José: Editorial Mirambell.

Quesada, A. (1998). Unos y otros. Identidad y literatura en Costa Rica (18901940). San José: Editorial de la Universidad de Costa Rica.

Rojas, M. y Ovares, F. (1995). Cien años de literatura costarricense. San José: Editorial Farben Norma.

Rojas, M. y Ovares, F. (1995). El último baluarte del imperio. San José: Editorial Costa Rica.

Rodríguez, F. (2013). Lisímaco Chavarría. Obras Completas. Tomos 1 y II. San José: Editorial de la Universidad de Costa Rica.

Rodríguez, H, A. (1956). Tesis. Lisímaco Chavarría. Instituto Superior de San Ramón.

Sotela, R. y otros (1940). Poesías de Lisímaco Chavarría. San José: Imprenta Nacional.

Semanario Universidad. Disponible en: https://semanariouniversidad.com/cultura/san-ramn-conmemora-centenariode-la-muerte-de-lismaco-chavarra/. 16 de enero 2013.

Zelaya, R. (1904). Orquídeas por Rosa de Chavarría. Páginas Ilustradas, V. 1(22), pp. 338-339. 